\title{
'Is Painting a Representation of Visible Things?' Conceptual Reality in Greek Art: A Preliminary Sketch
}

\author{
Tonio Hölscher
}

\section{Introduction}

Recent approaches to Greek and Roman art unanimously and emphatically stress the character of images as visual and material 'constructions' (Bažant I985; von den Hoff and Schmidt 200I). This concept is held by the most advanced, thoughtful and serious voices of art history, and it is applied to all kinds of figurative representation, from individual figures to multi-figured scenes, through all genres and periods of ancient art. Thus, Richard Neer sees Archaic statues as 'signs' to which the concept of likeness to real persons is fundamentally alien (Neer 2OI2: I IO-I2). François Lissarrague interprets scenes of a warrior's departure on Athenian vases as non-realistic constellations of the Greek oikos (Lissarrague I990: 35-53). Wolfgang Ehrhardt analyses the Alexander mosaic from Pompeii as a purely fictitious depiction of the historical battle between Alexander and Darius III (Ehrhardt 2008).

Of course, one can only agree with these approaches: they have led to important insights into the social meaning and cultural significance of Greek and Roman art. The following reflections are by no means meant to contradict such positions. Nevertheless, there is a fundamental problem. For the Greeks themselves conceived art as a practice of mimēsis, imitation (Pollitt I974: 37-4I, 46-8; for mimēsis in Greek art, see Stewart I990: $73-85)$. Thus, the title of this chapter, quoting Socrates' initial question in his discussion with the painter Parrhasios, as it is reported in Xenophon's Memorabilia, literally anticipates an obvious answer: yes, painting is a representation of visible things, that is, of their visible appearance (Xen. Mem. III, IO, I; Preisshofen I974). Therefore, the scope of this chapter is to reconcile the emic with the etic view, that is, our constructivist approach to ancient art with the definition of art in antiquity. It is with great admiration for Anthony Snodgrass and his pioneering work on early Greek art that I submit these considerations for his critical examination.

Of course, the Greeks were always aware of the fact that images were not identical doubles of 'real' beings or objects but artificial re-presentations, 
made in various materials, and they realised that this implied a specific 'artistic' activity, employing technical skill (the most penetrating analysis: Neer 2013: I-I9, to which I cannot do justice in this place). In this sense, the term mimésis covers a certain spectrum from copy to re-creation and re-enactment. Nevertheless, stress is laid not on creativity but on imitation, not on difference but on similarity or congruity between reality and art. In later discourses on art, terms like aletheialveritas and similitudo testify to the same basic categories of art. All these terms indicate not production but re-production (Pollitt I974: I70-87).

At the basis of our modern problems with these terms is a specific antithesis between 'reality' and art. Reality is conceived as an 'objective' material world of beings and objects, as it is physiologically perceived by the human senses, measurable in space and time, underlying physical and chemical processes of cause and effect, without any additional meaning, while art is conceived as a realm of visual objects and images of cultural significance and meaning. Starting from these notions, reality and art are thought of as opposing realms: genuine art transcends reality.

Yet, this is our 'modern' understanding of reality and realism: the physical world of objects and beings, 'objectively' documented without the distortions of human construction of meaning. The concept of objectivity, in the sense of measuring and reproducing reality in its contingent material form, originated in the nineteenth century, supplanting older concepts of perception and reproduction that aimed at recognising and representing 'reality' in its normative forms (Daston and Galison 2007). On these modern premises, Greek art is measured in relation to a concept of objective reality, exposed to objective perception and requiring objective reproduction - to which it does not correspond. This procedure is not illegitimate as long as it is consciously and explicitly meant as a view 'from outside', confronting our own concept of reality with that of historical cultural systems: in this sense it helps to create an awareness of basic aspects that separate these cultures from our own concepts. Normally, however, such diagnoses of un-realistic construction presuppose a universal concept of 'reality' which is transcended more or less intentionally by those images. This kind of argument leads to the above-mentioned contradictions with the notion of mimēsis. Moreover, it is evident that establishing deviations from our concept of reality means stopping halfway because it keeps ex negativo within the horizon of our own categories. The vital question - the only one that may extend the horizon of our own preconceptions - should focus on those strange Greek concepts of reality, perception and 'mimetic' image-making that are at the basis of Greek images.

In principle, this question concerns two different realms of art: themes and forms. Both realms require different theoretical concepts. Nevertheless, in the end the question of their interrelation will arise. In this first attempt the focus is on themes.

The following considerations are aimed at demonstrating the fundamentally mimetic character of Greek art: Greek images are in principle not intentional constructions of contents that transcend reality. Their 'sense' is 
emphatically contained in and expressed by their intentional reference to reality: they are 're-presentations' of 'conceptual realities'. This argument will be developed in four steps, looking at representations of fighting:

First, it will be argued that the underlying antithesis of 'mere' contingent reality as an object of 'realistic' visual perception and reproduction, on the one hand, and aesthetic representation by an 'image' that confers to this reality some visual meaning, on the other, appears to be problematic. For not only the image but also the 'reality' represented by it is a cultural construct. On these premises the interrelation between the image and its subject changes in an essential way.

Secondly, it will be asked, looking at some concrete examples, by which procedure images of 'real' events, persons and objects are produced. Thereby it will be argued that the representation of 'reality' and the construction of 'significance' are so intimately connected that they cannot be conceived as antithetical practices.

Thirdly, it will be argued that two characteristic themes of Greek art, naked bodies and battle scenes, both of which are traditionally considered examples of idealising transformations of reality, are in fact deeply related to concrete social 'realities'. In this sense the term 'conceptual realism' will be proposed.

Finally, some specific motifs of battle depictions are taken into account: objects of material culture and 'participating' beings that transcend the reality of concrete perception but are to be understood as real representatives of the conceptual order of the world.

\section{Reality versus art?}

The problems with the antithesis of 'mere' reality and 'meaningful' art can be demonstrated by a photograph of Giorgio de Chirico (Fig. I I.I; Hölscher and Lauter I995: I I-I3). It depicts the artist in a distinguished interior, furnished with works of Classical art. Cardigan and cravat are signs of an artist's garb and of social ambitions. He presents himself, with his heavy upright body and his hand propped on his hip, in a self-conscious pose, his head decidedly turned to his right, and his eyes intently focused on a far horizon.

The newspaper where this photo was published gives in its caption the following explanation: 'His ruler-like pose and his gaze into the distance are not staged for this birthday photograph, they have become, after decades of polemical distance from the present, the painter's second nature'. His physical habitus, clothing and surroundings are manifestations of his social and cultural ambition; his natural posture has become a significant pose. This stylised reality intentionally reflects the famous work of art, the bust of the Apollo Belvedere, which shows a similar gaze into the distance. In this context the painter himself becomes a living image, similar to the ancient portrait statue of the tragedian Sophocles who demonstrates by the same physical habitus his claim to normative significance. 


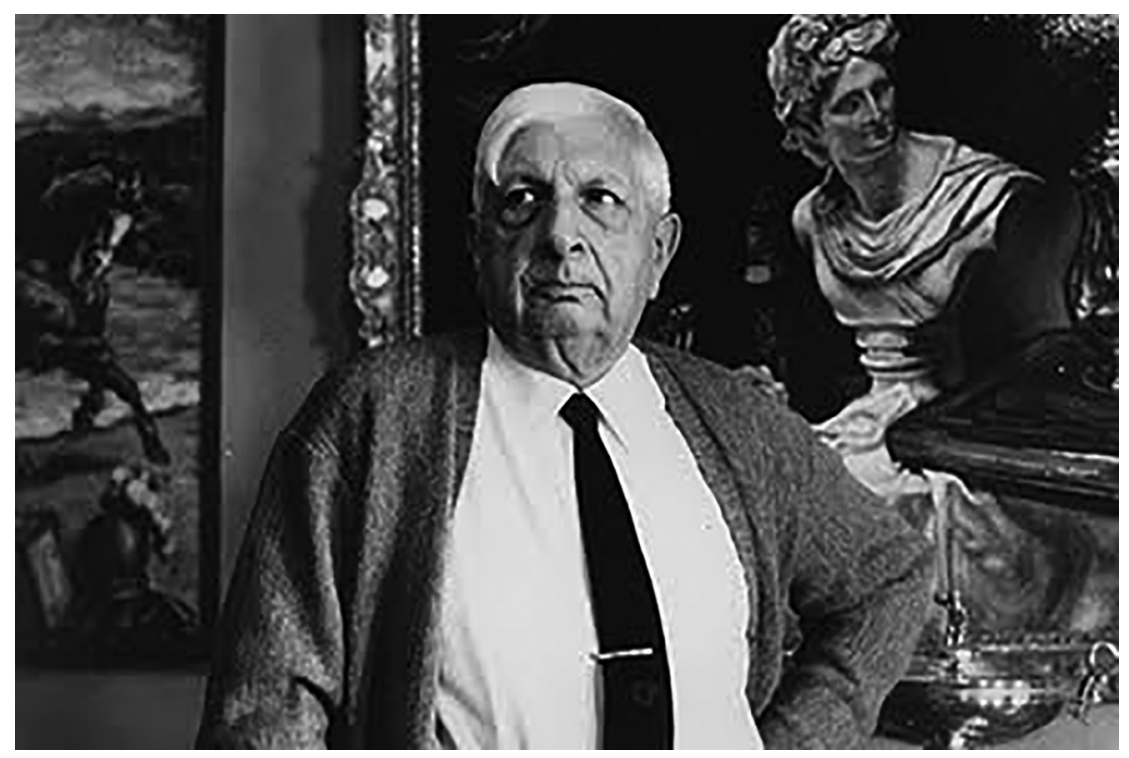

Figure 11.1 Giorgio de Chirico. Photo: Courtesy Frankfurter Allgemeine Zeitung and Horst Tappe.

Is this a view of a real person in his real living space - or is it a picture? Indeed, all motifs in this photograph are consciously arranged into a highly complex configuration of a living person, a work of art, and various objects constituting 'his' space. What we see is a picture that represents a man in the pose of an image, compared to an image in the picture. But behind this picture there is a real man who is very conscious of his visual appearance and who styles his appearance into an 'image'. This reciprocal amalgamation between a real appearance and an artistic creation elucidates in a pointed way the general interplay between what is termed an 'image' on the stage of social life and in the figural arts; or, more precisely: between an image, conveying significance to reality, and reality, stylised into a significant image.

Similar phenomena are to be observed in antiquity. Politicians and monarchs, such as Pericles and Alexander the Great, Caius Marius and Augustus, are reported to have styled their real appearance in a significant way, as a visual expression of their intended public 'role', corresponding to their public portrait statues which expressed these same qualities in their specific material medium (Hölscher and Lauter I995; Hölscher 2009: 26-32).

These observations can be generalised. Every individual shapes himself or herself into a kind of significant appearance: through hairstyle and beard, dress, jewels and cosmetics, and moreover through facial expressions, gestures, attitudes, movements and actions. These are visual manifestations of social roles and of cultural identity. Man is his own image. De Chirico is an example of highly conscious self-stylisation, but the same 
applies to all social levels: whether we dress well or sloppily, move in a disciplined or uncontrolled way, look grim or serene, we always say something about ourselves.

From individual persons one can proceed to scenes of interaction and interpersonal situations. As an example one may look at one of the most frequent scenes in Greek vase painting, Archaic as well as Classical: the departure of a warrior from his family for a war campaign (Lissarrague I990: 35-53; Spiess I992). The young man, in more or less complete armour, mostly faces a woman, either his mother or his wife; in addition, there often appears his old father, rarely some other member of the family. In Classical times they are usually performing a farewell libation, the woman pouring wine into the bowl held by the departing warrior. The atmosphere is earnest and full of sadness, all of them visualising the young man's possible death and the ensuing destruction of the hopes for the family's future.

Obviously, these scenes are consciously constructed situations. On a famous red-figure stamnos the figures are united in a composition of archetypal antithetical constellations: the young man and his wife, framed by his parents: the old father standing behind the woman, the mother at his own back (Fig. I I.2; Simon and Hirmer I976: pl. 205-7). Thus, the typical representatives of a Greek family are set into a systematic order of interrelations: man and woman represent the antithesis of gender and at

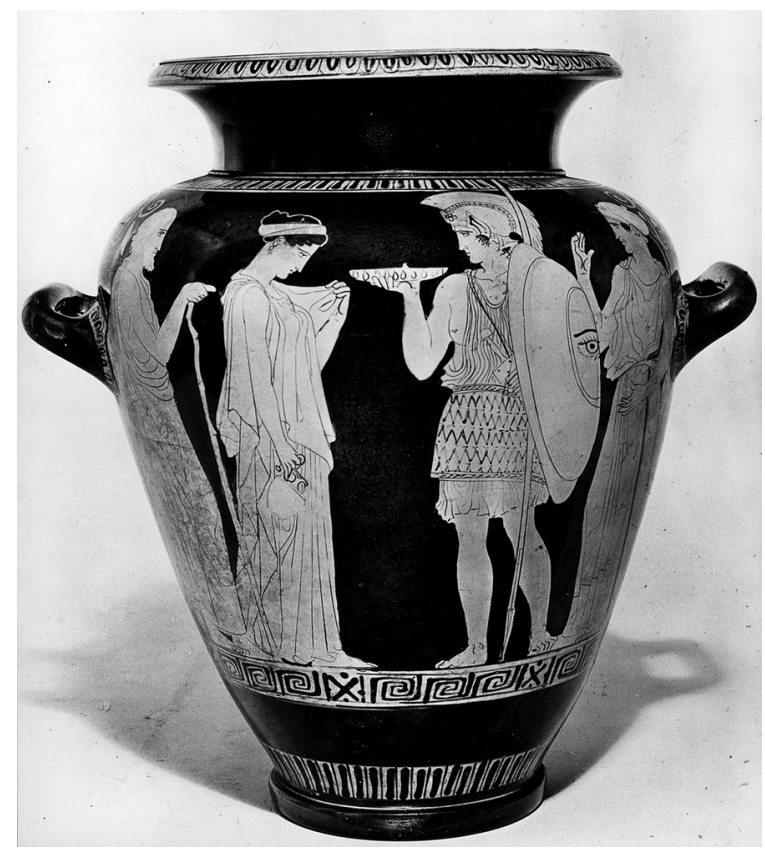

Figure 11.2 Departure of a warrior. Red-figure stamnos. München, Antikensammlungen. M. Tiverios, Ellenike Techne (Athenai 1996) pin. 160. 
the same time of the realms of house and war, inside and outside. Son and father stand for the antithesis of generations and at the same time of vigorous activity and dignified wisdom. Mother and wife denote the two forms of family ties, birth and marriage. Among these intersecting oppositions the constellation of warrior and wife is given priority.

Nevertheless, this is not to be understood as a case of a merely factual departure scene of real life which only in art is transformed into a systematic concept of an ancient oikos. For real departures too were in antiquity, and are to this day, realised in specific forms through which the community of those who separate constitutes its inner coherence. Thus Alcestis, in Euripides' tragedy, takes leave from her world, her Lebenswelt, in a very conscious sequence of farewell (vv. I 89-2 I2). First, she performs the last libations at the palace's altars, then she separates from her marital bed; thereafter she bids farewell to her children and to the servants; then she speaks to her parents-in-law who refused to sacrifice themselves instead of her - and finally she turns to her husband Admetus. This sequence in time of different farewells emphasises a hierarchy of relations between Alcestis and her social environment comparable to the special constellation of the oikos as it is depicted in the vase painting. In other images the warrior could be represented facing his father, as the young man might have bidden his last farewell in real life to the father of the family. Thereby, too, the family is represented in a significant configuration. While the playwright describes priority of farewell in an ascending sequence in time, the vase painters depict it through the constellation of figures in space.

This is comprehensible up to the present day. When we take leave for some extended absence, we consciously choose whom we want to be with us: our nearest friends, our family. And we bid farewell to them in a significant sequence: last to the children and to the marital partner, if possible alone. Thus, in real life too farewells are to a high degree conceived and shaped as conceptual performances. If we look at their visual aspects, they appear as sequences of meaningful 'images'. It is this 'conceptual reality' that is re-presented in art.

In this sense, the whole horizon of the Lebenswelt, as it is defined by Alfred Schütz and Thomas Luckmann (I973), can be seen and interpreted as a spectrum of visual manifestations of meaning, that is, as 'images'. It contains on the one hand the wide range of social actions: intentionally shaped performances, such as rituals and ceremonies; traditional forms of behaviour, such as orders of assemblies and symposia, forms of military combat, jurisdiction and table manners; finally, purely functional and uncontrolled activities, such as visiting the agora or working in workshops. On the other hand it comprises the material surroundings: intentionally shaped urban Stadtbilder, with civic and sacred architecture, conditioning human activity and behaviour and expressing visual meaning; objects of daily use, such as vessels, furniture and tools, charged with social value; and natural surroundings, such as mountains and the sea, groves and fountains, which are perceived as meaningful elements of life. In antiquity, these were never, nor are they today, purely material components of 'reality'. 
Applying these considerations to the problem of mimēsis and construction in art, some conclusions impose themselves:

- To conceive images representing motives of the Lebenswelt as constructions that inform themes of (neutral) 'reality' with 'significance' means to assume a problematical interrelation between reality and art. No doubt, images transform the 'reality' of the Lebenswelt on the basis of their working materials, according to collective rules of style, expressing specific concerns and messages of their authors, artist or patron, and responding to anticipated expectations of their audiences. However, the real Lebenswelt itself is not only a pre-given neutral material object: it too is a cultural construct with marked visual aspects conveying the visual significance of beings, objects and the surrounding nature.

- The attribution of visual significance to beings, objects and the elements of the Lebenswelt is on the one hand achieved through culturally informed perception: we focus on such aspects of reality as are significant to us; on the other hand it is achieved through more or less intentional shaping (Schütz and Luckmann I973). Both activities are accomplished in the frame of established social and cultural practice. Living as a cultural being in one's Lebenswelt always means orienting oneself in a conceptually interpreted and shaped, meaningful reality.

- The visual aspects of the conceptually experienced Lebenswelt merge into a meaningful image. This 'image character' of the Lebenswelt can be determined according to how far the visual forms of beings, objects and elements of real life are shaped or perceived as carriers of visual meaning. Conversely, the visual representation of beings, objects and elements of nature in material media - if it is not a mere mechanical reproduction, generated fortuitously and without any intention - can be termed an 'image' in so far as it conveys visual meaning.

- It is this interpreted, meaningful reality that is the subject of 'realistic' art. Images translate and transform phenomena of the Lebenswelt, that are charged with meaning in their real appearance, into other material media through specific techniques and methods of 'artistic' shaping, reaching from conceptual reproduction to more or less strong transformation. In antiquity, there seems to have prevailed, at least in general, a more or less strong coincidence in the meaning of themes in reality and in art.

- Images and the Lebenswelt of beings, objects and elements of nature are two parallel 'media' in and by which, through interpreting perception and intentional shaping, conceptual meanings are generated. This does not imply any identity between reality and image: rather, meaning is produced in both 'media' according to their specific potential of shaping. Yet there is no hierarchy between 'reality' and art in creating visual meaning.

- On these premises the notion of mimèsis becomes understandable in a concrete sense. Art does not supply neutral reality with additional meaning but translates and transforms meaning into meaning. 
- From this it follows that an image that, by its forms of representation, expresses some significance and meaning of its topic is not thereby in opposition to 'reality', as is often argued.

\section{Representing and understanding}

The themes of images are, as a rule, not precisely pre-given in reality. In ancient Greece, the most frequent task of artists was representations of gods and heroes and depictions of myths. However, nobody had ever encountered Athena or Heracles, nor had anybody witnessed, for example, the murder of Troilus by Achilles or the capture of Troy with the assault of Ajax on Cassandra. There were texts - which, however, did not provide any sufficient evidence of the visual impact of such figures or scenes. For themes of contemporary life, such as fighting in war, rituals of sacrifice or training in the palaistra, artists could acquire direct visual experience, but this was a perception of innumerable different motifs of moving, acting and interacting individuals, not yet crystallised into an image. How was mimessis put into practice under these conditions?

An artist, whatever subject he or she was going to represent, and whatever precise information he or she had about it, had necessarily to invent or to choose the concrete form of depiction. This 'compulsion to concretion' is a basic condition of artistic work. It works in representations of general as well as of specific themes (Hölscher I973: I4-I 5).

\section{Some simple examples}

First, a general theme: a Greek warrior defeating a Persian foe. This topic is not at all an unequivocal prescription for visual 'reproduction' in vase painting (Fig. II.3 Muth 2008: 239-67). The artist, intending to produce a 'realistic' depiction, may be acquainted with the forms of Greek armour and even with the types of Persian dress, trousers and sleeved jackets, made of multicoloured textiles. But no source or 'information' told him whether the Greek aggressor comes from the right or the left, whether he uses his lance or his sword, whether he slashes from above or stabs from below, whether his adversary opposes him or turns to flee, whether he is still on foot or falling to his knees, on his right or left knee, and so forth. The artist, forced to give his depiction a concrete form, has to decide on the whole composition as well as on every detail. These, however, are the features that convey to the depiction its visual impact.

Secondly, a specific event: the famous assassination attempt on the Athenian tyrants Hippias and Hipparchos by a couple of homoerotic friends, Aristogeiton and Harmodios, at the Panathenaic festival of 5 I 4 вС (Fig. II.4 Simon I975: pl. 42). The vase painter, intending to depict this event some forty years later, must have known that the assassins attacked and killed the younger brother in the agora with their swords, which they had hidden in a bunch of myrtle branches. This, however, was 


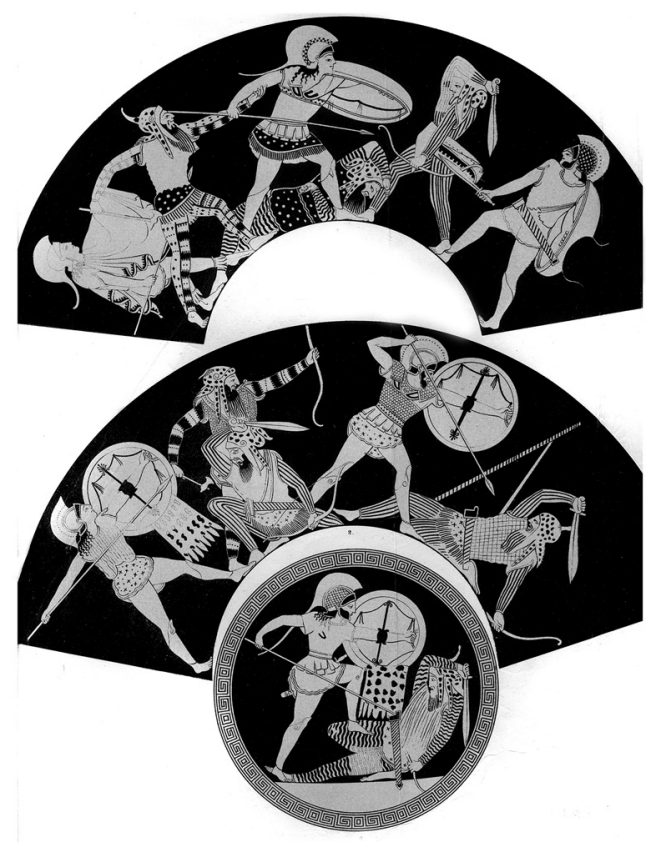

Figure 11.3 Greeks fighting Persians. Red-figure cup. New York, Metropolitan Museum of Art. S. Muth, Gewalt im Bild (Berlin 2008), Abb. 163.

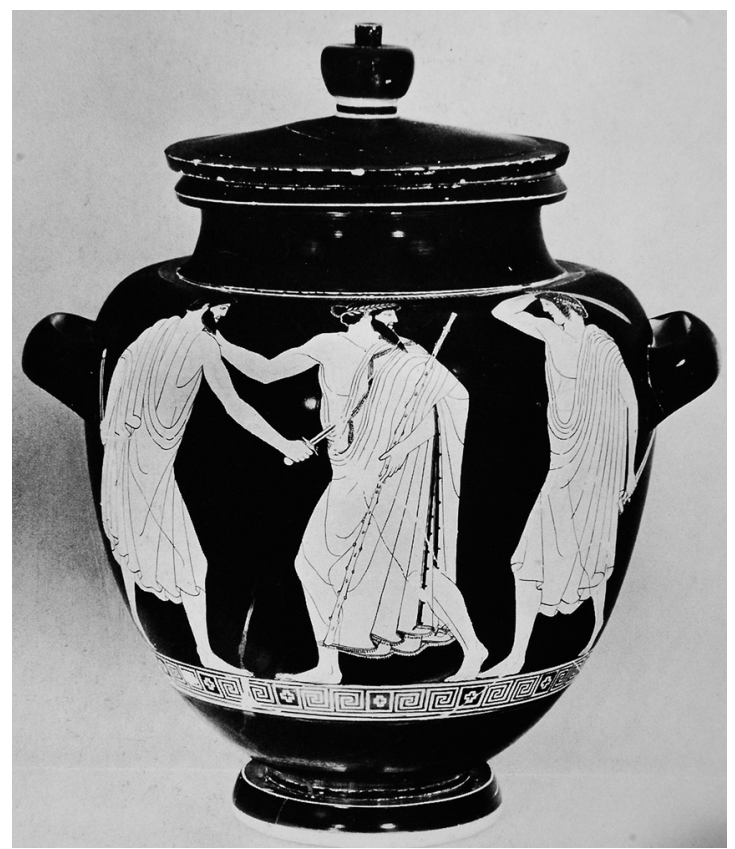

Figure 11.4 Aristogeiton and Harmodios assassinating Hipparchos. Red-figure stamnos. Würzburg, Martin-von-Wagner-Museum. 
totally insufficient for producing an image, since for this purpose he had to decide whether the assassins attack from one side or from both, how they put their weapons into action, whether their victim defends himself or flees, begging for mercy or breaking down, holding onto his staff or dropping it; not to speak of more subtle details: whether the aggressors advance vigorously or cautiously, whether their clothes cover their body completely or leave them in part visible, how the folds are arranged; and so forth. Nobody could tell how all this had happened 'in reality' - but the vase painter had to produce a concrete depiction in all details. Thus, he decided to depict this event as it could have happened - and at the same time corresponding to some idea of the political, social or ethical values inherent in this exploit: he represents the assassins' mutual devotion as a homoerotic couple by their appearance as an older man and a youth, emphasises their unanimous solidarity by their coordinated advance from both sides, while their victim, holding his staff without using it to defend himself, vaguely implores his murderer, looking back towards the other assailant. Furthermore, the vase painter distinguishes the impetuous character of the younger Harmodios, who brandishes his sword over his head and thus exposes his body, from the fierce determination of the older Aristogeiton, who stabs his sword into his victim's breast. The painter foregoes the myrtle branches, thus minimising the cunning of the two men and stressing their courageous character. More politically, he characterises the tyrant by his lavish hairstyle and elaborate long dress, in contrast to his opponents' simple 'democratic' haircuts and shorter clothes. All this is the painter's decision in the inevitable act of producing a concrete and, in its concreteness, meaningful image. Nevertheless, he produces in all respects an image of the real event.

This, however, has its consequences for how to understand this scene. Regarding the factual event, the viewer could gather from the vase painting the assassination as such but not the details of specific motions, actions, gestures and attitudes in specific moments. These, however, are not only imaginations of how the event could have happened concretely, but moreover, in their concrete appearance, also suggestions about the event's intended meaning.

From such simple examples we may proceed to some more complex compositions which have caused controversies of interpretation.

\section{The Alexander mosaic}

First, a well-known representation of an 'historical' subject: the Alexander mosaic from Pompeii, universally acknowledged as a more or less faithful copy of an early Hellenistic painting, depicting a battle between Alexander the Great and Darius III with their armies (Fig. I I. 5 Hölscher I 973: I 22-69; Andreae I977; Stewart I993: I30-50; Cohen I997; Pfrommer I998; Stähler I999; Moreno 200I; Ehrhardt 2008). This masterpiece of Greek painting was for long valued as the epitome of artistic 'realism', whereas recently it has been reinterpreted as an aesthetic construct far from any 


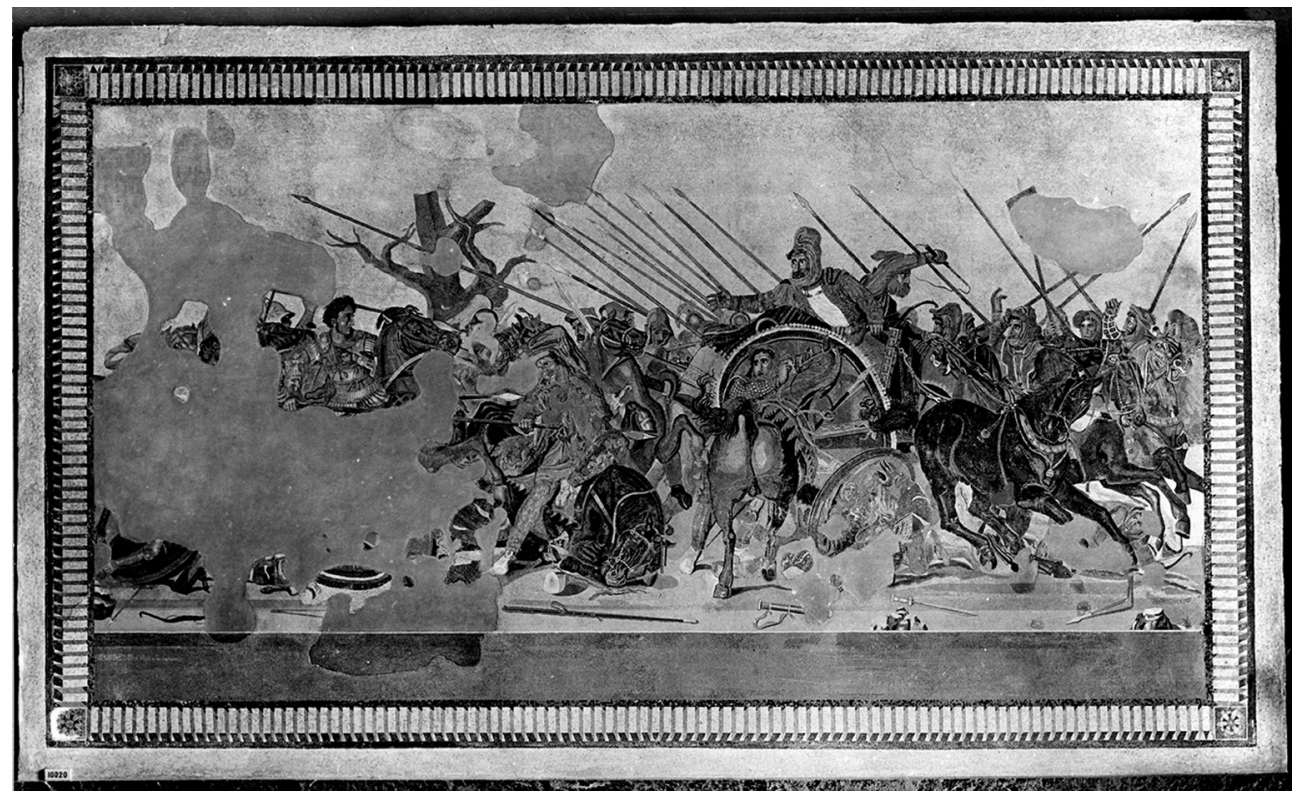

Figure 11.5 Alexander's battle against Dareios III. Mosaic from Pompeii. Napoli, Museo Nazionale. Deutsches Archäologisches Institut Rom.

historical reality. Its main subject, Alexander at the head of his cavalry rushing headlong into the centre of the Persian army, attacking the Great King who turns in flight on his huge chariot, is claimed to have nothing to do with any specific battle. It is argued, on the one hand, that the composition is shaped by figurative strategies that are also used for other subjects, and on the other hand that it serves ideological messages about the roles of the royal protagonists that lead far beyond the reality of any specific event. Thus, although the mosaic/painting may intend to represent the battle of Gaugamela in $33 \mathrm{I} \mathrm{BC}$, the composition is held to depict not a real military encounter but an imagined war, a Krieg im Kopf: 'pure fiction'.

Yet how could the 'reality' of any battle between Alexander and Darius be depicted? More than two hundred thousand Persians against some forty thousand Greeks? All of them in their 'real' armour? In their specific spatial motions of military units and in their 'real' individual attitudes of fighting and falling, pursuing and fleeing? As they appeared in the same 'real' moment? Of course, this concept of 'realism' is absolutely excluded, first because this kind of mass panorama exceeds the possibilities of an image, secondly because no witness had the knowledge or memory of hundreds of thousands of individual actions. This is a banality - but it is precisely this concept of 'realism' that is implied in diagnoses of a 'non-realistic' construction of images: visual depictions present intentionally cut-out details, they concentrate actions in space and time within the frame of an image, they represent motions and attitudes, bodies and equipment as an imagined reality, according to the artist's general knowledge of 'reality' and to established 
models of representing it. What else can an artist do, even if he or she aims at a depiction as realistic as possible?

The event depicted in the mosaic is highly complex. Alexander with his entourage has forcefully advanced near to Darius. At the last moment two Persian noblemen on horseback throw themselves into Alexander's path, one of them being transfixed by Alexander's lance and crashing down on his horse. Another Persian is trying to control a wildly rearing horse, obviously intending to enable his king to flee. In the background a Greek detachment is encircling the Persian centre with their lances on their shoulders. At the last moment, however, the royal charioteer drives his team aggressively out of the turmoil, disregarding his own men who are crushed by the chariot's nailed wheels and trampled by the horses' hoofs.

The mosaic composition is to a high degree conceptually designed. The scene chosen does not describe the entire battle but concentrates on the encounter of the two royal protagonists. These are characterised as great political and ethical opponents: Alexander rushing impetuously forward at the head of his army, Darius vaguely turning backwards and forwards; Alexander aiming his lance for a deadly blow, Darius having spent all of his arrows, holding his useless bow; Alexander being integrated with his troops, at the same level, a primus inter pares, Darius towering on his huge chariot high above his men, an absolute monarch. The armies also are depicted in marked opposition: the Macedonian cavalry advancing from the left in a compact cuneiform formation, while the detachment in the background performs a disciplined manoeuvre; the Persians disorganised, with some courageous noblemen sacrificing themselves desperately for their king, whereas the majority appears paralysed with fear, without visible armour, while others are brutally run over by the king's chariot.

These messages are presented with great visual effect through the painting's composition. The protagonists are brought together as near as possible without involving them in direct combat (which in fact never happened). All actions are fused in one coherent moment. Many characters are depicted in established schemes of motion and attitude, which are also adopted in art in other contexts: the assaulting heroic rider, the collapsing horseman, the energetic horse-tamer, the fleeing king on his chariot.

Yet-does the image thereby become a pure construct, a Schlacht im Kopf that has nothing to do with reality? A kind of 'fiction' (Ehrhardt 2008)? Clearly, this is no photograph. If one scholar recently tried to determine from the oblique shadows thrown by the figures the precise time of day the battle (of Gaugamela) was fought (Moreno 200I: I 5-I 8), this is of course a grotesque projection of a concept of art as factual 'documentation'. Nobody will infer from the mosaic that Alexander came to within four metres of the king's chariot, that Darius in the same moment extended his arm in despair, that Alexander speared his opponent rendering his lance unusable, and that at the same time the royal mount went wild. All these motives are 'concretisations' of the event in the sense of 'possible reality', without any claim to historical authenticity. For the same reason, however, they can by no means be adduced as arguments against a possible reference to a specific historical 
battle. They are just indispensable devices for achieving concrete vividness. And they serve to convey to the depiction the strong significance and powerful impact on the viewer. Obviously, this is no offence against authenticity, and even less against 'reality'.

The depicted battle is full of meaning, political, ideological, cultural. But the real battle too is not an objective event of meaningless factuality: it too is thoroughly imbued with, and visually shaped by, its ideological and cultural 'significance'. In fact, Alexander conceptualised his major battles against the Persians as a personal agon between himself and the Great King - and according to this concept he conceived his real battle tactics. At Issos as at Gaugamela he actually aimed to defeat the enemy king personally, advancing indeed near to his chariot - yet in the end he could only put Darius to flight. To achieve this, Alexander used in fact to put himself at the head of his elite cavalry, imitating the heroes of myth who acted as the protagonists of their armies, unlike generals of his time who commanded their troops from afar. In the same sense, the painting emphasises the antithesis of royal weapons, which corresponds on the one hand to reality but at the same time to an old ideological topos: Alexander's lance as a symbol of Greek courage, direct fighting 'hand to hand', and Darius' bow as a sign of insidious and cowardly fighting from a distance, characteristic in particular of eastern 'barbarians'.

Similarly the real opposing armies were charged with ideological concepts. The compact discipline of Greek troops was stamped by, and glorified as, an ethos of mutual coherence, whereas the Persian troops were said to be weakened by cowardice and effeminacy, submission to a despot, at best disposed to useless self-sacrifice. Of course, there were many stereotypes and clichés at work, but these were conceptual patterns according to which reality was perceived, understood - and to some degree even actively shaped: in the modes of fighting and in many other kinds of cultural practice. The roles and behavioural patterns of social actors unfold in visible forms. In this sense, the real battle, too, was a 'picture'.

In this respect, the antithesis of the 'real' battle in 'real' life on the one hand and the 'fictional' battle im Kopf turns out to be of limited relevance. The 'real' battle, too, takes place im Kopf. There is no reason why the Alexander mosaic should not represent a specific battle, say that at Gaugamela, as a 'conceptual reality'.

Of course, the 'picture-like' battle of real life and the depicted battle of art are far from identical: in real battles people are really put to death. Yet both battles are imbued with meaning, and this meaning comes to the fore in the 'real' appearance of beings, objects and actions. The physical world of bodies and objects on the one hand and the depicted world of art are two media with their specific conditions and possibilities, technical and social practices, modes of acting and perceiving. There is no question - and what has been said should by no means be understood as contradicting this - that in many respects art disposes of wider possibilities of reproducing 'conceptual reality'. But there is no antithesis of 'realism' and 'construction of meaning'. 
Battles in vase painting

Still more complex, and more revealing, are anonymous scenes of military combat in Archaic vase painting (Fig. I I.6 Knittlmeyer I997: 46-79; Muth 2008: I42-238). They are usually seen as idealising transgressions of reality. Normally, multiple battle scenes are represented as sequences of individual fighting: mostly duels of two opponents, often contending over the body of a fallen warrior, at most supported by one or two companions. From literary sources, however, we know that in Archaic times battles were fought in more or less compact formations. Correspondingly, there is, besides the innumerable duel compositions in Greek art, a limited number of Archaic vase paintings and Classical relief friezes depicting closed battle formations opposing each other (Fig. II.7). Thus, Greek art was indeed able to represent the contemporary way of collective fighting. All the more striking is the fact that artists so rarely made use of this possibility. Is this a deviation from 'reality'? And if so, why are there those utterly divergent modes of representation?

Explanations for this alleged deviation of art from the 'real' practice of fighting are not lacking. Mostly scenes of individual fighting in duels or small groups of hoplites are interpreted as retrospective references to Homeric ideals of heroic warfare. Indeed, as is well known, Homer's heroes prove their arete in individual fighting against individual opponents. In this

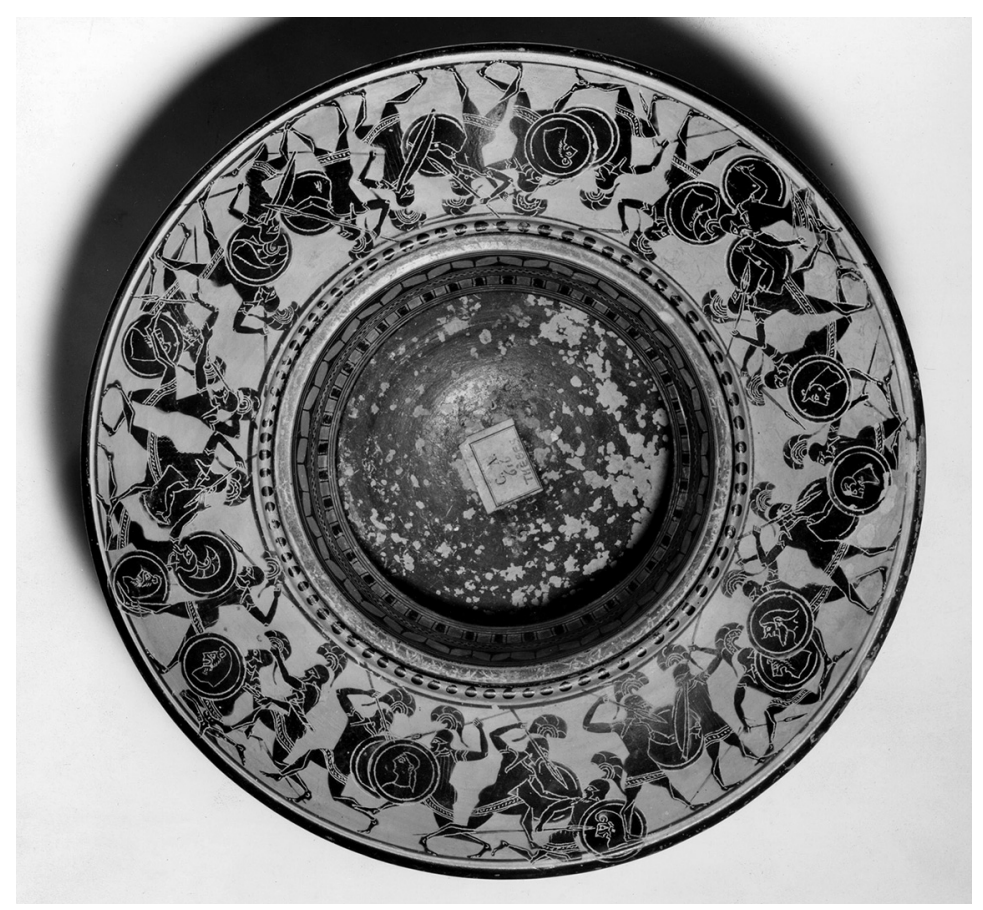

Figure 11.6 Battle of hoplites. Black-figure exaleiptron. Paris, Louvre. E. Simon, M. Hirmer, Die griechischen Vasen (München 1976) Taf. 58. 


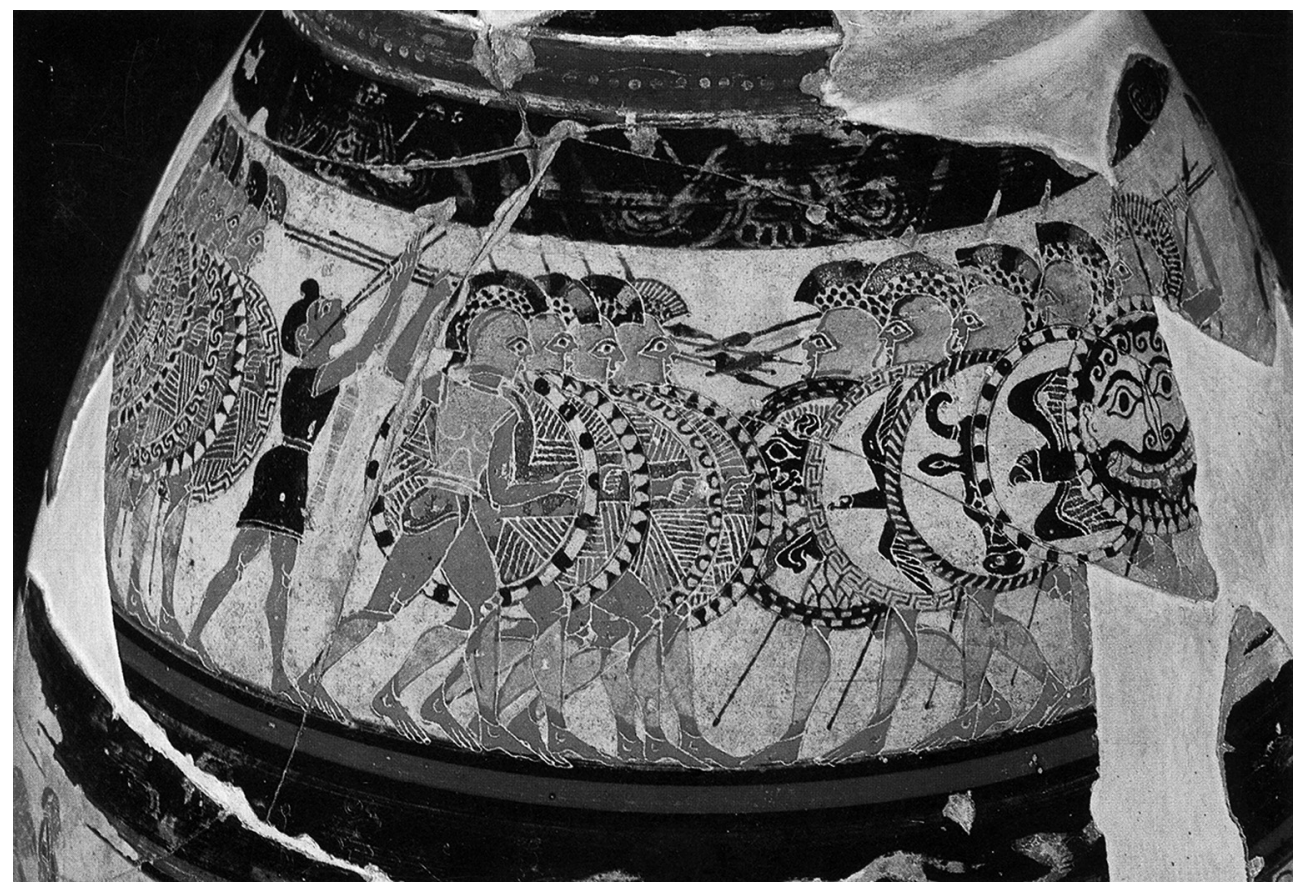

Figure 11.7 Hoplite phalanxes. Corinthian olpe. Rome, Villa Giulia. E. Simon, M. Hirmer, Die griechischen Vasen (München 1976) Taf. VII.

view the whole sphere of war would be, through all periods of Greek history, pervaded by a deeply retrospective, idealising and heroising attitude regarding the practice of war, removing from reality this omnipresent sphere of actual life (Ellinghaus I997). Before accepting such contradictions, one may ask whether the concept of individual duels, as it is represented in art, was in fact so far from the reality of Archaic and Classical warfare.

This question can only be approached by distinguishing three levels: the reality of battle tactics, the experience of the reality of battles, and their representation in art.

Regarding real warfare, it is impossible to discuss in this place the manifold controversial questions of the so-called phalanx: whether it existed from early times or was introduced in some later period, and when precisely, how it was put into action, in what kind of cooperation, by what use of armour and weapons, and so forth (for a summary, see Rawlings 20I3: I8-24). Without any doubt, however, at the time when closed lines of hoplites were depicted on vases, real armies were drawn up and led into the battle in more or less compact formations. As has often been stressed, this kind of packed battle tactics was not a fortuitous military technique, but was deeply rooted in the social structures of this period. Its foundation was the middle class of peasants who formed the (more or less) 'civic' army, developing in battle some collective coherence among themselves, protecting and standing up for each other. 
To what degree and in which concrete forms these tactics of collective fighting were realised in actual warfare is difficult to say. What is clear, however, is the fact that this was a conceptual attitude that had a strong impact on the notion and experience of war. For military coherence was intimately connected to a general ideal of civic equality, homoiotes, that prevailed among the middle classes as a political claim for full recognition within the citizen body. It is this aspect of war practice that comes to the fore in the collective scenes of hoplite fighting (Cartledge I977; Spahn I977; Snodgrass I993; Lendon 2005).

Yet why, then, is there such a predominance of individual fighting in the majority of battle scenes? If it is right to assume that Greek armies indeed advanced into the battle with a strong tactical and ethical coherence, it is equally evident that this attitude must have been eclipsed and more or less dissolved as soon as the lines of battle were at close quarters. There were no overarching strategies and tactics, no interplay of different military units, no collective movements and actions. Basically, every warrior came to stand face to face with one or very few opposing warriors, being at most supported by some of his neighbours. This situation must have been massively enhanced by the 'Corinthian' helmets, limiting the gaze to the immediate opponent by their small eye-slots, and reducing acoustics to the noise of the immediate vicinity (Hanson I989; Lendon 2005). Thus, the collective body of the army must have basically disintegrated, becoming a mass of individual fighters. This change is precisely described on the Macmillan aryballos: first, at the left, there appear two closed battle lines; then, towards the right, fighting is displayed in individual duels, face to face (Fig. I I.8).

As a result, war was obviously conceived of and experienced as a practice of manly valour in which the immediate encounter of hoplites and the capacity of fighting man to man were all-important. Tyrtaeus, the great poetic whip of Spartan fighting ethics, is very precise about this: first, warriors should advance in closed formation, 'side by side', protecting their following companions - but then they are spurred on to face their immediate opponent, 'foot against foot, shield against shield, helmet against

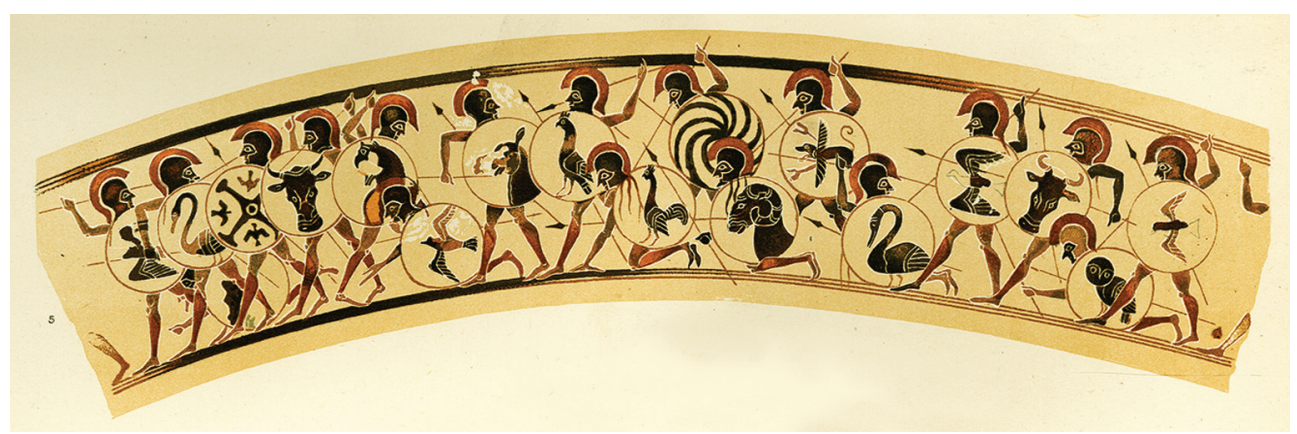

Figure 11.8 Battle of hoplites. Proto-Corinthian Macmillan aryballos. London, British Museum. Journal of Hellenic Studies 10 (1889) pl. V. 
helmet, crest against crest, chest against chest, each man with sword in hand or far-injuring spear' (Tyrtaeus fr. I I, 29-34 West). The collective and the individual complement each other - but in the end single combat is the more exciting experience. This, therefore, is also the mental sphere where the predominant social values are developed: social recognition is founded on individual valour and achievements, in war as in other realms of life (Stewart I997: 89-92; 2014: 227-32; see also Hölscher I973: 28-30; 2003 b: 4-6; Knittlmeyer I997: 67-7I; Shanks I999: I07-I9).

It is this aspect that is experienced in real warfare and is represented in art. The experience, however, as well as the representation is based on a specific practice of real fighting which resulted in the predominant role of duel combats. In this sense, the depiction of battle scenes in the form of duel or group fighting is no intentional deviation from the contemporary reality of warfare, no retrospective stylisation according to Homeric models, no anachronistic idealisation or heroisation following the major characters of myth, but an emphatic representation of vital experiences made in the contemporary reality of war.

\section{Nudity}

Among the most significant devices of Greek art, often quoted as the most obvious proof of its non-realistic character, is male nudity. As is well known, male figures were depicted in Greek art in various contexts with naked bodies. This conforms to the real appearance of young men in the realm of athletics, who appeared with naked body while training in the palaistra or competing in games in the big sanctuaries. But in other sectors of life, such as warfare or hunting, the depiction of naked bodies is in plain contradiction to the practice in real life. Not to speak of the irritating portrait statues of individual persons with naked bodies in the agora or in public sanctuaries.

The traditional understanding of male nudity as a sign of 'ideal' or 'heroic' character, elevating those represented beyond their real human appearance to 'ideal' significance, seems to be losing acceptance (Himmelmann I990; Stewart I997: 24-42; Hölscher 2003a; Daehner 2005; Hurwit 2007). While this interpretation could seem plausible regarding images of gods and mythical heroes, and even for representations of famous men like Alexander the Great or virtuous warriors, to whom in this way hero-like qualities might be ascribed, it is contradicted by naked bodies in other contexts where intentions of idealisation or heroisation are out of the question: defeated foes on battle friezes and grave reliefs, revelling youths after the symposion, working craftsmen in their workshops, slaves, and so forth.

An even-handed approach to this artistic device has to start from the fundamental significance of the body in Greek culture. A few remarks must suffice in this context. Greek culture, which can be defined as a 'culture of immediate action', was to a very high degree founded on the human body. Whatever human beings did, achieved and suffered, they did, in the Greek view, primarily with and through their bodies. 
Training the body in the palaistra for achieving strength and beauty was the primary goal of Greek education; rituals of transition to adulthood and citizenship were accomplished by the public unveiling of the body for examination. Social recognition and success depended above all on the impact of a person's public performance and outward appearance. Political issues were negotiated by all citizens in bodily presence. For hunting, notoriously a central activity of male valour, Plato prefers 'direct' physical fighting against wild beasts, with lance and sword, to technical devices with nets and traps (Laws $823 \mathrm{~b}-824 \mathrm{c}$ ). In this general sense, the valorous male body was considered the essential factor in warfare. Thus, when Agesilaos and his Spartans were once confronted with a far-outnumbering Persian army and his men began to despair, he ordered that some Persian captives be presented naked to them, uncovering their pale bodies which had never been trained in a Greek palaistra - whereupon the Greeks reported an overwhelming victory in the following battle (Xen. Hell. II.4.20).

These nude bodies were presented in scenes of figurative art as factors of Greek valour in war, whereas other figures were depicted with cuirasses, demonstrating the military and social value of elaborate hoplite armour. Both modes of representation, nudity and armour, are situated on the same level of 'reality'. On the other hand, it is equally through nude bodies that the suffering and death of defeated enemies, the effort of working craftsmen or the ignoble nature of slaves can be depicted. Regarding the question of realism, the crucial fact is that these are the real bodies of these characters: it is the concrete body of the warrior that is considered essential for his military valour and success, the real body of his opponent that is experiencing defeat, of the craftsman that is performing hard labour, of the slave that is held to show his inferior nature and his burdensome life. Thus, there is no idealisation, no heroisation, no elevation above 'mere' reality. To qualify such representations as non-realistic is only justified if surface visibility is made the decisive criterion of 'reality'. There are, however, plausible reasons for dismissing this criterion in favour of a notion of reality that comprehends those elements that are held essential notwithstanding the circumstance that they are in fact hidden from view by clothes or armour. In this sense, nudity in battle scenes can be conceived as even more realistic than the covered bodies that correspond to surface perception.

\section{Armour and equipment}

The main elements of armour and other kinds of equipment, as represented in art, conform more or less, taking into account some stylisations of rendering, to contemporary material culture. There are, however, some exceptions which deserve further comment. One of them, a favourite theme of Anthony Snodgrass, is the oblong 'Boeotian' shield which seems to have been out of use in the sixth century ВС (notwithstanding Boardman I983: 29-32) when it appears abundantly in scenes of fighting, mythological as 
well as anonymous. Whether or not this type of armour is derived from the 'Dipylon' shield on eighth-century вС vases (in my view still a plausible explanation), it seems in any case to have conveyed some grandeur to its bearers. Accepting this derivation, two possible explanations have been proposed for the anonymous scenes: either they intend to represent events from myth, without making explicit identifications; or they depict 'daily life' scenes in a kind of retrospective idealisation, conveying to them a general 'heroic' or 'Homeric' flavour (critical assessment: Snodgrass I980: 56-7; Knittlmeyer I997: 6I-3).

Yet the fundamental question is whether in this early period objects of material culture were regarded at all with a 'historical' eye, understanding their different forms as variations in time, and assigning them to specific periods of the past and the present. Thucydides' famous conclusion from the grave finds on Delos about the provenance of the ancient inhabitants of the island from Caria (book I.8) has always been praised as a revolutionary step of fifth-century $\mathrm{BC}$ historical thinking. Projecting this into the Archaic period seems to be a questionable procedure. Indeed, whether such shields, or their typological predecessors, had once really existed or not, they must have appeared to be an actual potential reality, and no concept of historical thinking will have imposed on the viewer the idea that this was an object that belonged, or referred, to a bygone 'heroic' past (see Giuliani 2010).

Similar considerations may explain the appearance of war chariots with warriors appearing in anonymous battle scenes (Greenhalgh 1973: 6I-2, 90, I I9; Knittlmeyer I997: 63-4; Manakidou I994: pl. I0, I). In Homer the heroes use their chariots for riding onto the battlefield where they then fight on foot. The assumption that in sixth-century BC hoplite battles some noble warriors fought standing on their chariot seems to lead to an impasse: fighting on war chariots cannot have been in use at the time of hoplite formations. Again, however, the conclusion that this is an element of retrospective 'Homeric' idealisation seems to be problematic: as in the case of 'Boeotian' shields, there is no reason for attributing to this period, without further discussion, a concept of seeing material culture in the dimensions of 'historical' time. In the past, chariots had been used in the context of war; in present days, chariots were used not only by contenders in chariot-races but also by noble aristocrats in religious processions to distant sanctuaries (and why not also for reaching the battlefield?). In any case, this motif is better understood, not as a transgression beyond, but as an extension of reality - with no specific reference to the past but on the basis of present social practice, without considering the possibility of 'historical' changes (Boardman I983: 28-9; Giuliani 2010: 38-40).

Another phenomenon that transcends the material reality of warfare is those figurative devices that adorn the warriors' shields (Fig. II.9): the Gorgon and similar monsters, lions, rams, snakes and other frightening beasts, and so forth. In real war practice, such devices were fixed as flat material attachments to the shield's surface - but conceptually they were imbued with some actual power: thus, one could speak of them as of living 


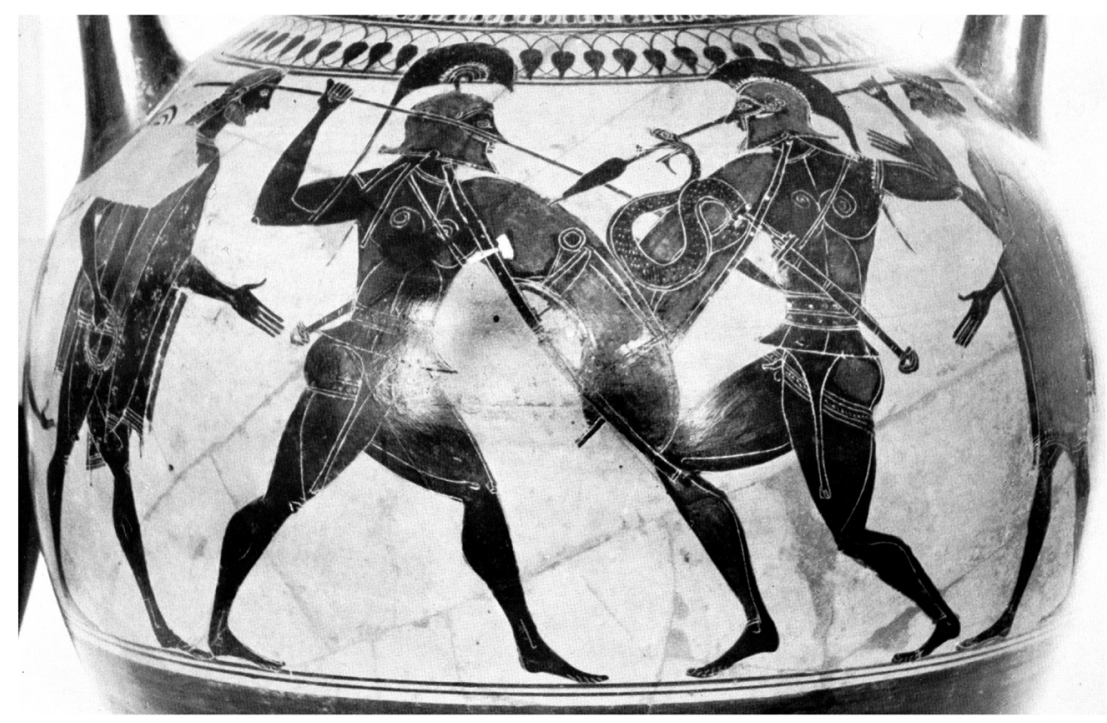

Figure 11.9 Hoplite with shield design. Black-figure amphora. Boulogne-sur-Seine, private collection. H. Mommsen, Der Affecter (Mainz 1975) Taf. 111 above.

beings. And this aliveness was given an impressive expression in art. Often, flat shield devices turn in the direction of the warrior's opponent, intensifying the assault of their 'master'; in such cases depictions remain on the level of what is materially possible. Sometimes, however, such creatures turn, in corporeal aliveness, towards 'their' enemies. Snakes, in particular, transcend all possible forms of material attachments to real shields. Considering the potential life and power that are attributed to real shield devices, it becomes evident that the qualification of this mode of representation as unrealistic would be misleading: it is a kind of ultra-realism by which these devices are given the vital power that is attributed to them in 'real' life (Grabow I998: I70-92; Philipp 2004: 62-I 57; Hölscher 20I4: I70-I).

Observers of battles: human beings and gods, wild animals and monsters

As is well known, fighting scenes are often framed by beings that in real life cannot have been immediately present at these events (Fig.I I.IO). Most frequent are human observers, male as well as female, in 'civic' attire, looking at and reacting to the encounters of warriors. Of course, these are no 'realities' at the edge of the battlefield: they are representatives of the families and the citizen body, mothers, sisters and wives, fathers, brothers, friends and fellow citizens, conceptually participating in the destinies of those who risk their lives for them, testifying to the social importance of the event, and conveying honour to the combatants. Together with them they appear in antithetical constellations: war versus home, male versus 


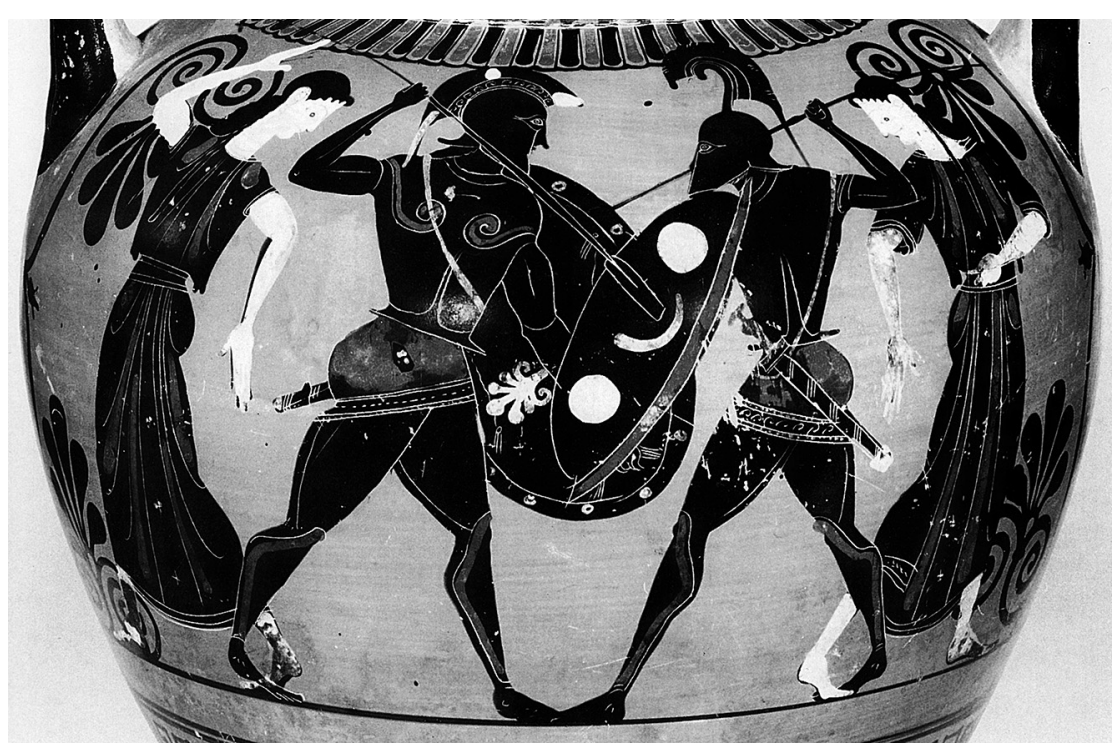

Figure 11.10 Fighting hoplites with female observers. Black-figure amphora. London, British Museum. J. Burow, Der Antimenes-Maler (Mainz 1989) Taf. 135 below.

female, old age versus youth, a structural constellation of the civic society, in clear deviation from visible reality.

But is the qualification as 'unrealistic', true as it may be, really helpful? For obviously, there is some 'reality' to this scene. The archetype of Greek war duels, the fight between Achilles and Hector, was observed (obviously from the city wall of Troy) by Priam and Hecuba, from the beginning, when Achilles first appeared, to the end, when he had brutally slain his opponent; and with the royal couple we may imagine the whole community of Trojan elders, women and children, fearing for and lamenting the destiny of their brave fighters (Homer, Iliad XXII). This is the 'real' social and emotional background of the observers framing the battle scenes in vase painting: they bring the real families' and citizens' participation to the fore, regardless of spatial distances. Such scenes are unrealistic only if 'correctness' of spatial relations is regarded as an essential feature of 'reality'. Anthony Snodgrass has emphasised the importance of 'synoptic' representation of time in Archaic art (Snodgrass I982; I998: 55-66): here we are facing 'synoptic' depiction of space. As soon as the criterion of measurable space is dismissed, this mode becomes even a way of representing more reality than in a photographic reproduction.

In a few scenes, not of fighting but of the departure of a warrior from his family, the goddess Athena makes her appearance (Fig. I I.I I; Lissarrague I990: 45-6). This may be understood as an 'ideal' replacement of those citizens who on many vases used to frame the duels of fighting: the city goddess acting as an 'abstract' personification, definitely unrealistic, of the city and its citizen body. Yet there may be more 'realism' in such 


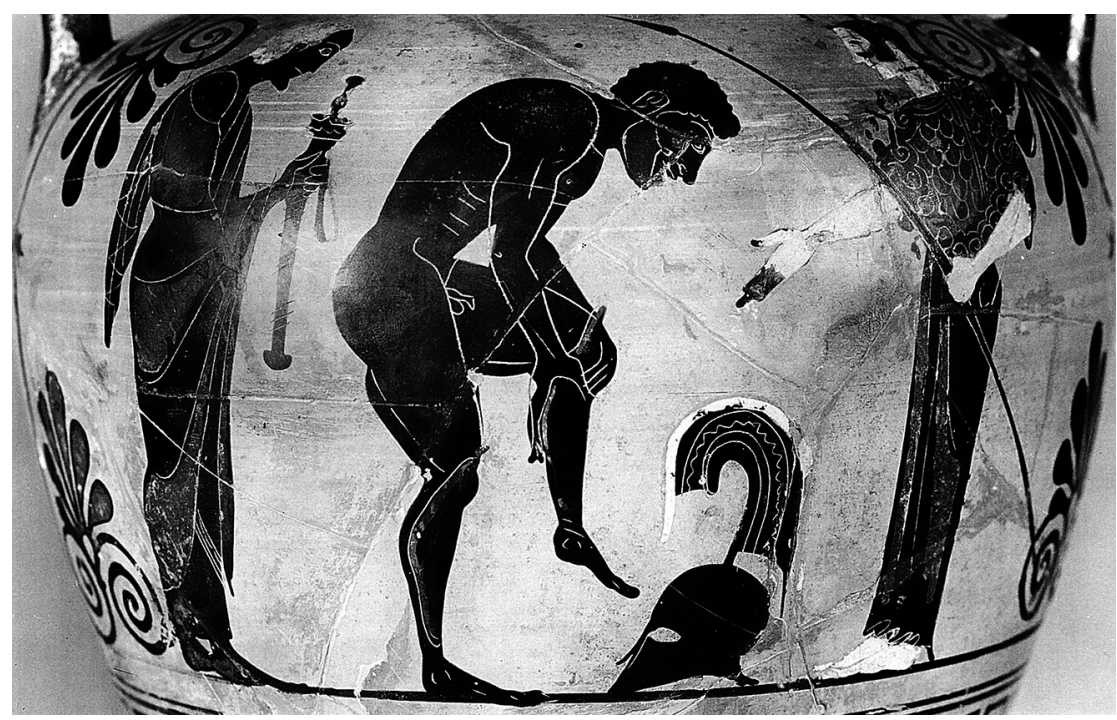

Figure 11.11 Departure of a warrior, with Athena. Black-figure amphora. Rome, Musei Capitolini. J. Burow, Der Antimenes-Maler (Mainz 1989) Taf. 66 below.

scenes: for one should not forget that in the Greek view the gods were real beings who were potentially present in all situations of life. In the famous painting of the battle of Marathon in the Athenian Stoa Poikile, the city goddess Athena was depicted as the leading power of her citizens, together with Heracles, who was conceptually present in his sanctuary near the battlefield; with Theseus, whom many participants claimed to have seen during the battle in full armour, leading the Athenian army; and with some other heroes who allegedly had helped in person against the Persians (Pausanias I.I 5.3; Hölscher I 973: 60-5). These are varying degrees of reality which are overlooked if the image is assessed according to rational categories of material visibility.

Finally, in some early Archaic vase paintings scenes of hoplite fighting are set in an environment of wild beasts and monsters. On a ProtoCorinthian aryballos two fighting hoplites appear at the side of two antithetical sphinxes; on other vases scenes of war are combined with animal friezes (Fig. I I.I2). The world of untamed nature, omnipresent in the arts of the 'Orientalising' period, has been interpreted as an unor pre-civilised state in antithesis to the cultural order of the emerging polis (Shanks I999: 90-I07). In this sense, hoplite war, as a controlled practice of fighting, is assigned a systematic place between the wilderness of aggressive animals on the one hand and the peaceful order of the civic space on the other. Seen in this sense, vases and other decorated objects present a highly 'constructed' constellation of the world.

Yet again, this is just one side of the coin. For this is precisely the way in which the real world was perceived and experienced (Hölscher I999: I7-20; Winkler-Horacek 2000; 20I 5). The world of wild and frightening animals was not conceived as an abstract antithesis to the human order of 


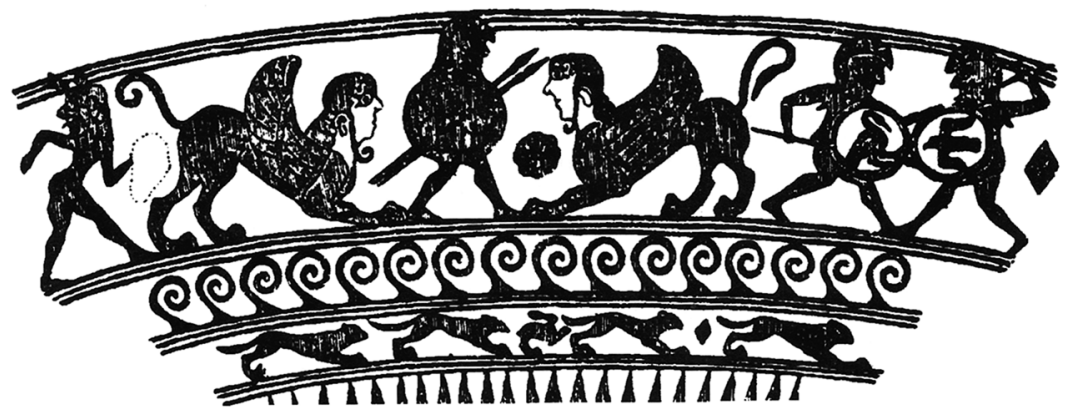

Figure 11.12 Fighting hoplites with sphinxes. Proto-Corinthian aryballos. Athens, National Museum. M. Shanks, Art and the Greek City State (Cambridge 1999) fig. 3.19, 3.

life, but was localised in specific parts of the conceptual world: in those liminal areas of woods and mountains that surrounded the cultivated territory of Greek cities, and in the remote regions beyond human civilisation, at the 'end of the world', near to Oceanus. The inner 'circle' of wild surroundings was a space of ferocious beasts, like boars, and peaceful animals, like wild goats; from hearsay and imagination lions and panthers could be added, without consciously moving from imagined reality to pure fantasy. In a world which was not yet totally explored there were no clear borderlines between experience, knowledge, imagination and fantasy. Heracles was reported to have fought in such areas against wild creatures that reach from experience to imagination: the boar of Mt Erymanthus, the lion of Nemea, the snake-monster of Lerna, even the hybrid manhorse Centaurs of the woods of Pholoe. There is no change of the level of 'reality'. Greek poleis were conceived as islands of order in the midst of violent nature (Plato, Prot. 320-3). It is in this - at the same time real and conceptual - 'outside' sphere that vase painters locate battle scenes. Of course, the juxtaposition of animals and warriors does not mean they are at a distance of two metres, but in a wider sense they are acting in the same space.

\section{Conclusion: conceptual realism}

In speaking about 'realism' in Greek and Roman antiquity, we have to take into account that we are dealing with a period, and a society, where 'reality' was conceived in categories different from our own.

There is no reason to doubt that Greek artists and viewers conceived and perceived scenes of battles with groups of face-to-face fighters as depictions of real war experience. Equally, they must have viewed nude warriors as re-productions of 'reality': in fact, such depictions represented those 'real' bodies that were decisive for success in war. The same is true of representations of nude defeated enemies, working craftsmen or ignoble slaves: it is their 'real' body that is meant to show their valour in victory or 
their suffering in defeat, their labour or their ignoble nature. An antithesis to 'reality' can only be stated in such depictions if 'reality' is understood according to the criterion of physiological perception or mechanical photography. But what kind of criterion is this? Why should we qualify elements of concrete reality, which only by specific conditions are withdrawn from direct view, as unrealistic?

Moreover, when artists conceived of figurative shield devices as active forces, when they imagined gods and heroes as active supporters, and the fighters' relatives and fellow citizens as sympathising participants, they represented real actors of the event. Even the wild animals and monsters that frame some scenes of real-life battles and of various mythological events are to be understood as imagined representatives of the liminal regions where such scenes took place. These participants become unrealistic only if their pure material visibility and not their real conceptual participation is made the crucial criterion.

We make our distinction between material reality and 'significant' art on the assumption of a neutral Lebenswelt, open to objective perception and reproduction, which in art is transformed into a significant visual construct. Yet the Lebenswelt itself is perceived and formed by human beings as a meaningful kosmos. Art translates meaning into meaning.

Both, Lebenswelt and art, are conceptual realities. We may, from an etic perspective, be more interested in the concepts (of reality) in ancient images. But we should acknowledge that from the emic perspective of antiquity, images aimed at (concepts of) reality. In this sense art was mimetic and realistic (Hölscher 20I 5: $5 \mathrm{I}-7$ ).

These questions and considerations apply to factual themes and their composition. They need to be complemented by questions of style and its relation to reality. But this is another issue (see Dietrich 20II).

\section{Bibliography}

Andreae, B. (I 977), Das Alexandermosaik aus Pompeji, Recklinghausen: Bongers. Bažant, J. (1985), Les citoyens sur les vases Athéniens du 6e au 4e siècle av. J.-C., Prague: Academia Nacladatelstuí Československé Akademie Věd.

Beazley, J. D. (1963), Attic Red-Figure Vase-Painters, 2nd edn, Oxford: Clarendon Press.

Boardman, J. (I983), 'Symbol and story in Geometric art', in W. G. Moon (ed.), Ancient Greek Art and Iconography: Symposion Madison, Wisconsin, Madison: Wisconsin University Press, pp. I 5-36.

Campbell, B. and L. A. Tritle (eds) (2013), The Oxford Handbook of Warfare in the Classical World, Oxford: Oxford University Press.

Cartledge, P. (I977), 'Hoplites and heroes: Sparta's contribution to the technique of ancient warfare', JHS 97, pp. I I-27.

Cohen, A. (1997), The Alexander Mosaic: Stories of Victory and Defeat, Cambridge: Cambridge University Press.

Daehner, J. (2005), 'Grenzen der Nacktheit: Studien zum nackten männlichn Körper in der griechischen Plastik des 5. und 4. Jahrhunderts v. Chr.', JDAI I 20, pp. I 5 5-300.

Daston, L. and P. Galison (2007), Objectivity, New York: Zone Books. 
Dietrich, N. (20II), 'Archaischer Realismus', Jahreshefte des Österreichischen Archäologischen Instituts 80, pp. I3-46.

Ehrhardt, W. (2008), 'Das Alexandermosaik oder: Wie authentisch muss eine historische Darstellung sein?', in MDAI (R) I I 4, pp. 2 I 5-69.

Ellinghaus, C. (1997), Aristokratische Leitbilder - demokratische Leitbilder: Kampfdarstellungen auf athenischen Vasen in archaischer und frübklassischer Zeit, Münster: Skriptorium.

Fuhrmann, H. (I93I), Philoxenos von Eretria: Archäologische Untersuchungen über zwei Alexandermosaike, Göttingen: Dietrich.

Giuliani, L. (20I0), 'Myth as past? On the temporal aspect of Greek depictions of legend', in L. Foxhall, H.-J. Gehrke and N. Luraghi (eds), Intentional History: Spinning Time in Ancient Greece, Stuttgart: Steiner, pp. 35-55.

Grabow, E. (I998), Schlangenbilder in der griechischen schwarzfigurigen Vasenkunst, Münster: Scriptorium.

Greenhalgh, P. A. L. (I973), Early Greek Warfare, Cambridge: Cambridge University Press.

Hanson, V. D. (1989), The Western Way of War: Infantry Battle in Classical Greece, London: Hodder and Stoughton.

Himmelmann, N. (1990), Ideale Nacktheit in der griechischen Kunst, JDAI 26, Ergänzungsheft, Berlin: De Gruyter.

Hölscher, T. (I973), Griechische Historienbilder des 5. und 4. Jahrhunderts v. Chr., Würzburg: Triltsch.

Hölscher, T. (I 999), 'Immagini mitologiche e valori sociali nella Grecia arcaica', in F. De Angelis and S. Muth (eds), Im Spiegel des Mythos: Bilderwelt und Lebenswelt, Palilia 6, Wiesbaden: Reichert, pp. I I-30.

Hölscher, T. (2003a), 'Körper, Handlung und Raum als Sinnfiguren in der griechischen Kunst und Kultur', in K.-J. Hölkeskamp, J. Rüsen, E. Stein-Hölkeskamp and H. T. Grütter (eds), Sinn (in) der Antike: Orientierungssysteme, Leitbilder und Wertkonzepte im Altertum, Mainz: von Zabern, pp. I63-92.

Hölscher, T. (2003 b), 'Images of war in Greece and Rome: between military practice, public memory, and cultural symbolism', JRS 93, pp. I-I7.

Hölscher, T. (2009), Herrschaft und Lebensalter. Alexander der Große: Politisches Image und anthropologisches Modell, Jacob Burckhardt-Gespräche auf Castelen 22, Basel: Schwabe.

Hölscher, T. (2014), 'Im Bild noch lebendiger als in Wirklichkeit: Bildwerke, Lebewesen und Dinge im antiken Griechenland', in R. Bielfeldt (ed.), Ding und Mensch in der Antike, Heidelberg: Winter, pp. I65-96.

Hölscher, T. (2015), La vie des images grecques, Paris, Hazan.

Hölscher, T. and R. Lauter (1995), Formen der Kunst und Formen des Lebens, Ostfildern-Ruit: Cantz.

Hurwit, J. M. (2007), 'The problem with Dexileos: heroic and other nudities in Greek art', AJA I I I, pp. 35-60.

Knittlmeyer, B. (I997), Die attische Aristokratie und ibre Helden, Heidelberg: Archäologie und Geschichte.

Lendon, J. E. (2005), Soldiers and Ghosts: A History of Battle in Classical Antiquity, New Haven: Yale University Press.

Lissarrague, F. (I990), L'autre guerrier: Archers, peltastes, cavaliers dans l'imagerie attique, Paris and Rome: Ecole Française de Rome.

Lorimer, H. L. (I947), 'The hoplite phalanx with special reference to the poems of Archilochos and Tyrtaios', BSA 42, pp. 76-1 38 . 
Manakidou, E. P. (I994), Parastaseis me armata, Thessaloniki: Chardamitsa.

Moreno, P. (200I), Apelles: The Alexander Mosaic, Milan: Skira.

Muth, S. (2008), Gewalt im Bild: Das Phänomen der medialen Gewalt im Athen des 6. und 5. Jahrhunderts v. Chr, Berlin: De Gruyter.

Neer, R. (2012), Art and Archaeology of the Greek World: A New History, c. 2500-C. I5O BCE, London: Thames \& Hudson.

Neer, R. (20I3), The Emergence of the Classical Style in Greek Sculpture, Chicago and London: University of Chicago Press.

Pfrommer, M. (1998), Untersuchungen zur Chronologie und Komposition des Alexandermosaiks auf antiquarischer Grundlage, Mainz: Philipp von Zabern.

Philipp, H. (2004), Archaische Silhouettenbleche und Schildzeichen in Olympia, Olympische Forschungen 30, Berlin: De Gruyter.

Pollitt, J. J. (1974), The Ancient View of Greek Art: Criticism, History, and Terminology, New Haven and London: Yale University Press.

Preisshofen, F. (I974), 'Sokrates im Gespräch mit Parrhasios und Kleiton', in K. Döring (ed.), Studia Platonica: Festschrift für Hermann Gundert zu seinem 65. Geburtstag, Amsterdam: B. R. Grüner, pp. 21-40.

Raeck, W. (I98I), Zum Barbarenbild in der Kunst Athens im 6. und 5. Jahrbundert v. Chr., Bonn: Habelt.

Rawlings, L. (2013), 'War and warfare in ancient Greece', in Campbell and Tritle 2013 , pp. 3-28.

Schutz, A. and T. Luckmann (1973), The Structures of the Life-World, Evanston: Northwestern University Press.

Shanks, M. (I999), Art and the Greek City State, Cambridge: Cambridge University Press.

Simon, E. (1975), Fübrer durch die Antikenabteilung des Martin von Wagner Museums der Universität Würzburg, Mainz: Philipp von Zabern.

Simon, E. and M. Hirmer (I976), Die griechischen Vasen, Munich: Hirmer.

Smith, C. (г 890), 'A protokorinthian lekythos in the British Museum', JHS II, pp. $167-80$.

Snodgrass, A. M. (I980), 'Towards the interpretation of the Geometric figurescenes', MDAI (A) 95, pp. 5 I-8.

Snodgrass, A. M. (I982), Narration and Illusion in Archaic Greek Art: Eleventh J. L. Myres Memorial Lecture, London: Leopard's Head Press.

Snodgrass, A. M. (I993), 'The "hoplite reform" revisited', Dialogues d'Histoire Ancienne I9/I, pp. 47-6I.

Snodgrass, A. M. (I998), Homer and the Artists: Text and Picture in Early Greek Art, Cambridge: Cambridge University Press.

Spahn, P. (I977), Mittelschicht und Polisbildung, Frankfurt am Main: Lang.

Spiess, A. B. (1992), Der Kriegerabschied auf attischen Vasen der archaischen Zeit, Frankfurt am Main: Lang.

Stähler, K. (I999), Das Alexandermosaik: Über Machterringung und Machtverlust, Frankfurt am Main: Fischer.

Stewart, A. (1990), Greek Sculpture: An Exploration, New Haven: Yale University Press.

Stewart, A. (1993), Faces of Power: Alexander's Image and Hellenistic Politics, Berkeley: University of California Press.

Stewart, A. (1997), Art, Desire and the Body in Ancient Greece, Cambridge: Cambridge University Press. 
Stewart, A. (20I4), 'Two notes on Greeks bearing arms: the hoplites of the Chigi jug and Gelon's armed Aphrodite', in O. Dally, T. Hölscher, S. Muth and R. M. Schneider (eds), Medien der Geschichte: Antikes Griechenland und Rom, Berlin: De Gruyter, pp. 227-43.

Von den Hoff, R. and S. Schmidt (eds) (200I), Konstruktionen von Wirklichkeit, Stuttgart: Steiner.

Winkler-Horacek, L. (2000), 'Mischwesen und Tierfries in der archaischen Vasenmalerei von Korinth', in T. Hölscher (ed.), Gegenwelten zu den Kulturen Griechenlands und Roms in der Antike, Munich: Saur, pp. 2I7-44.

Winkler-Horacek, L. (2015), Monster in der frühgriechischen Kunst, Berlin: De Gruyter. 